\title{
TWO HETEROSTIGMATIC MITE SPECIES (ACARI: DOLICHOCYBIDAE, PODAPOLIPIDAE) ASSOCIATED WITH SCARABAEUS PIUS (COLEOPTERA: SCARABAEIDAE) FROM IRAN
}

\author{
Bahramian, M., Hajiqanbar, H.* and Talebi, A. A. \\ Department of Entomology, Faculty of Agriculture, Tarbiat Modares University \\ 14115-336, Tehran, Iran. E-mails: morteza.bahramian20@gmail.com, hajiqanbar@modares.ac.ir \\ and talebia@modares.ac.ir; ${ }^{*}$ Corresponding author
}

\begin{abstract}
During a study on insect-associated heterostigmatic mites (Acari: Prostigmata) in southern Isfahan Province, Central Iran, two colonies of mites were found on Scarabaeus pius (Illiger, 1803) (Coleoptera: Scarabaeidae): Pavania lanceolata sp. n. Bahramian et Hajiqanbar (Dolichocybidae) that is easily discernible by some modified foliate setae on tarsi I-III; and Tarsopolipus massai Husband, 1989 (Podapolipidae) for which Scarabaeus pius is a new host record.
\end{abstract}

Key words: Heterostigmatina, Pavania, Tarsopolipus, new species, host record.

\section{INTRODUCTION}

Beetles of the superfamily Scarabaeoidea are one of the most typical coleopterans, and even insects, to carry various kinds of mites. The mites from groups Mesostigmata, Prostigmata and Astigmatina encompass representatives associated with these beetles (e.g. Masan \& Halliday 2009, Costa 1963, Oconnor 1982, Houck \& Oconnor 1991, BochKov \& Klimov 2005, KaliszewsKI et al. 1995). In Prostigmata, some heterostigmatic families such as Dolichocybidae (Hajiqanbar \& Khaustov 2010), Scutacaridae (Ebermann et al. 2003), Pygmephoridae (Khaustov \& Trach 2012), Microdispidae (Hajiqanbar et al. 2012) and Podapolipidae (Husband 1989) include species that have relationships with this group of beetles. Some mentioned families have only phoretic relationship with scarab beetles (like Dolichocybidae, Pygmephoridae and Scutacaridae) however, some others are parasite of their hosts (like Podapolipidae).

The purpose of this paper is to describe a new species belonging to the genus Pavania associated with the Scarabaeus pius (Coleoptera: Scarabaeidae), compare the species with closely related congeners and report of the previously described species Tarsopolipus massai on the aforementioned scarab beetle, that provide a new host record for this parasitic mite. 


\section{MATERIAL AND METHODS}

Mites were removed from a scarabaeid beetle collected directly from their habitat, livestock dung pads. Mite specimens were cleared in lactophenol solution and mounted in Hoyer's medium. Terminology follows mostly that of Lindouist (1986) and in part (chaetotaxy of tarsus I of the Pavania) Rahiminejad et al. (2011). The morphology of the mites was studied by a light microscope with phase contrast (Olympus BX51). All measurements in the description are given in micrometers for the holotype and four paratypes in parentheses. In descriptions of the leg setation the number of solenidia is given in parenthesis. Details of geographical coordinates have been recorded using GPS. The scarabaeid host beetle was identified by G. V. Nikolaev (Al-Farabi Kazakh National University, Almaty, Kazakhstan). The holotype is deposited in the Acarological Collection, Department of Entomology, Faculty of Agriculture, Tarbiat Modares University, Tehran, Iran. One paratype is deposited in the Collection of Department of Animal Taxonomy and Ecology, A. Mickiewicz University, Poznan, Poland, and an other paratype in U.S. National Museum of Natural History, Washington D.C., U.S.A. Host beetle is retained with the holotype.

\section{TAXONOMY \\ Family Dolichocybidae Mahunka, 1970 \\ Pavania lanceolata Bahramian et Hajiqanbar sp. n. \\ (Figs 1-7)}

Diagnosis. The new species is characterized by some setae modified being foliate on the tarsi I-III (setae $p v^{\prime}, p v^{\prime \prime}, u^{\prime}$ and $u^{\prime \prime}$ on the tarsus I; $u^{\prime}, t c^{\prime \prime}, p v^{\prime}$, $p v^{\prime \prime}$ on tarsus II and $p v^{\prime \prime}$ on tarsus III); dorsal idiosomal setae smooth, bluntended (except $v_{2}, s c_{2}$ and $h_{2}$ pointed); seta $c_{2}$ two times longer than $c_{1}$; seta $f$ at least three times longer than $e$; seta $h_{2}$ about 6.8 times longer than $h_{1}$; ventral idiosomal setae smooth and needle-like; pharynx obvious, with four muscle lobes on each side.

Description. Female (holotype). Length of idiosoma 124 (128-128), width 76 (72-79).

Gnathosoma (Figs 1-2). Length 23 (23-24), width 19 (21-23). Gnathosomal capsule subquadrangular in dorsal aspect, longer than wide. Cheliceral setae $c_{1} 12$ (13-13), blunt ended; $\mathrm{ch}_{2} 6$ (6-6), pointed. Dorsomedian apodeme apparent. Cheliceral stylets 6 (6-6) curved and falcate. Subcapitular setae su 5 (7-8), stiff and located on anterior half of subcapitulum. Pharynx visible with four muscle lobes (Fig. 3). Palpi evident, exceeding apex of gnathosoma capsule. Femorogenu with setae $d G e 7$ (7-9) and $d F e$ 3 (3-3), both pointed; tibiotarsus with 2 solenidia; minute palpcoxal setae $p p$ inserted near to articulation of each palp on gnathosomal capsule.

Idiosomal dorsum (Fig. 1). Elliptic in shape. All dorsal shields ornamented with sparse dimples; posterior margins of C, D and EF shields with backward undulating projections. All dorsal idiosomal setae smooth. Prodorsal shield subtrapezoid, anterior margin convex, with setae $v_{1} 13$ (12-14); $v_{2} 5$ (4-5), $s c_{2} 49$ (49-50). Trichobothridia $\left(S c_{1}\right)$ present, broken in holotype and paratypes. Setae $v_{1}$ shorter than distance between their bases and blunt, $v_{2}$ short and located posterolaterally to $v_{1}$, seta $s c_{2}$ long and pointed. Median shield 
of tergite $C$ including setae $c_{1} 13$ (12-12), each lateral shield with one seta $c_{2} 25(22-25)$, both setae blunt; seta $c_{2}$ 2-times longer than $c_{1}$. Tergite $\mathrm{D}$ bearing setae $d 15$ (14-15), blunt; cupuli $i$ a situated laterally to seta $d$. Tergite EF with blunt setae $e$ (8-9) and $f 27$ (26-28), one pair of cupuli im placed anterolaterally to setae $f$, seta $f$ more than 3-times longer than $e$. Tergite H with setae $h_{1} 9$ (8-9) blunt ended and $h_{2} 61$ (59-61) long and pointed, seta $h_{2}$ about 6.8 times as long as $h_{1}$. Distances between dorsal idiosomal setae: $v_{1}-v_{1} 21$ (22-23), $v_{2}-v_{2} 27$

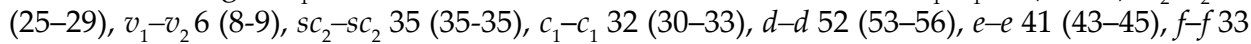
(33-35), e-f 10 (10-10), $h_{1}-h_{1} 13$ (12-12), $h_{2}-h_{2} 25$ (23-25), $h_{1}-h_{2} 8(6-8)$.

Idiosomal venter (Fig. 2). All ventral idiosomal setae smooth and needle like; apodemes II and III not reaching to presternal apodeme; apodeme IV joined to the poststernal apodeme. Coxal field I with setae $1 a 5(5-6), 1 b 5(6-6), 1 c 5(4-5)$. Coxal field II with setae $2 a 12$ (12-14), $2 b 6$ (5-6), $2 c 12$ (10-12); setae $2 a$ and $2 c$ subequal, both longer than $2 b$. Coxal field III with setae $3 a 10$ (8-11), $3 b 8$ (7-), $3 c 10$ (9-10); setae $3 a$ and $3 c$ subequal in length and both longer than $3 b$. Coxal fields IV with setae $4 a 7$ (7-7), $4 b 8$ (7-11), $4 c 8$ (7-9), all subequal.
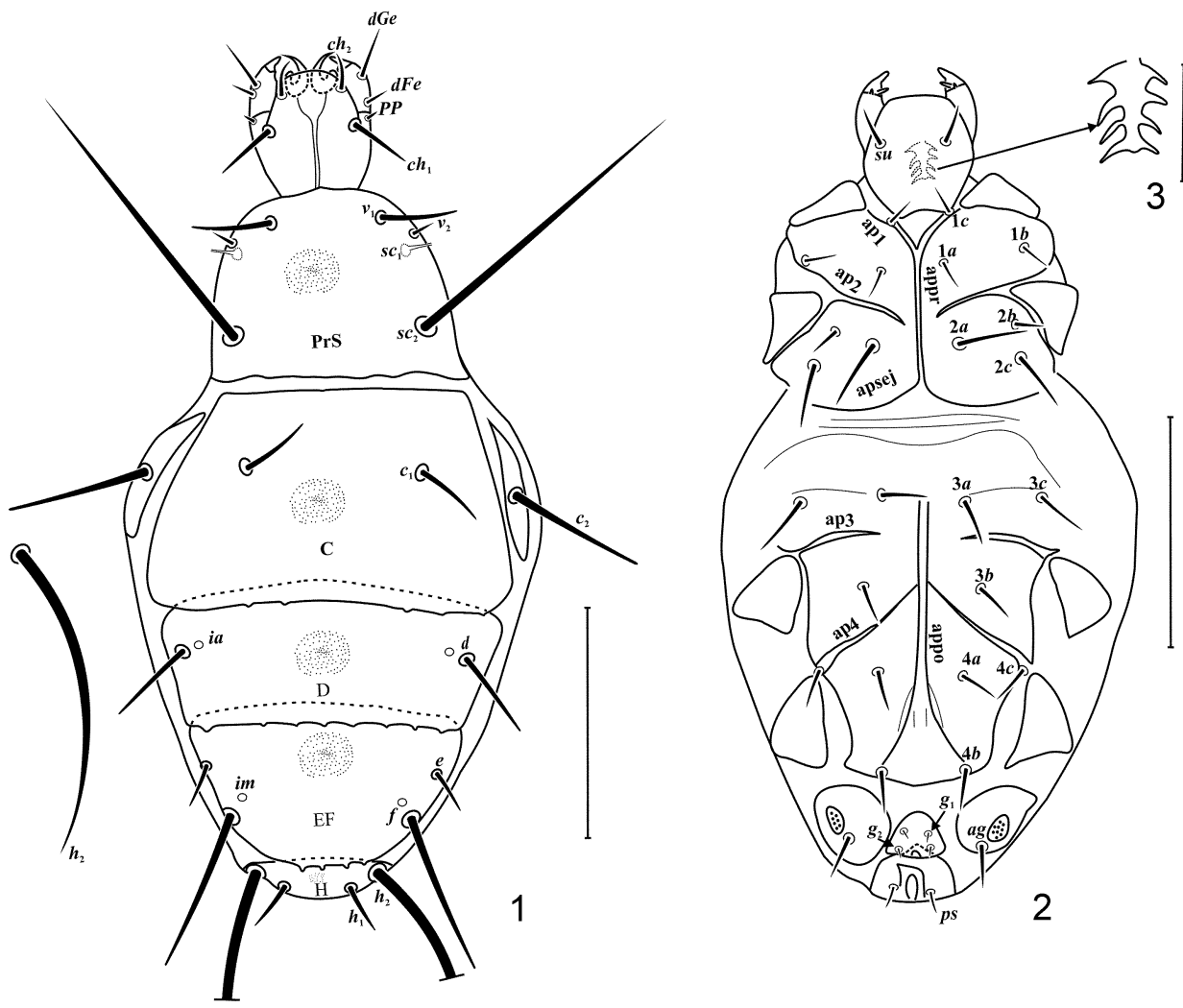

Figs 1-3. Pavania lanceolata sp. n., female: $1-2=$ gnathosoma and idiosoma, $1=$ dorsal view, 2 = ventral view (scale bars $50 \mu \mathrm{m}) ; 3=$ pharynx (scale bar $10 \mu \mathrm{m})$. 
Genital plate with setae $g_{1} 2(2-3)$ and $g_{2} 2(2-2)$. Aggenital plates each bearing 1 seta $a g 8$ $(6-7)$ and 1 small porous area. Pseudanal plate with setae $p s 3(3-4)$.

Legs (Figs 4-7). All setae of the legs smooth. Leg I (Fig. 4): with pair of claws and short, sessile empodium; setal formula: 4-2-6(2)-11(2). Tarsus: with setae $p v^{\prime}, p v^{\prime \prime}, u^{\prime}$ and $u^{\prime \prime}$ characteristically modified, lanceolate; setae $t c^{\prime}$ and $t c^{\prime \prime}$ subequal and longer than other tarsal setae; proral $\left(p^{\prime}, p^{\prime \prime}\right)$ and fastigial $\left(f t^{\prime}, f t^{\prime \prime}\right)$ setae subequal; solenidion $\omega_{1} 4(3-4)$ finger shaped and prominent; solenidion $\omega_{2} 2(2-2)$ baculiform. Tibia: with eupathidium $k$ stiff, tapering; solenidion $\varphi_{1} 6(4-5)$ stalked and finger shaped, longer than baculiform $\varphi_{2} 4(3-4)$; seta $d$ longer than other setae of the segment. Genu: setae $v^{\prime}$ shorter than $l^{\prime}$; seta $l^{\prime}$ subequal to tibial sata $l^{\prime}$. Femur: seta $d$ subequal to tarsal setae $t c^{\prime}$ and $t c^{\prime \prime}$ and more than three times longer than $l^{\prime \prime}$.

Leg II (Fig. 5). Setal formula: 2-1-4(1)-6(1). With pair of claws and large, stalked empodium. Tarsus: setae $p v^{\prime}, p v^{\prime \prime}, u^{\prime}$ and $t c^{\prime \prime}$ characteristically modified, lanceolate; solenidion $\omega 3$ (3-4) finger shaped; setae $p l^{\prime \prime}$ and $t c^{\prime}$ subequal. Tibia: solenidion $\varphi 3$ (2-3) similar to $\omega$ but thinner; seta $l^{\prime}$ shortest on the segment. Genu: seta $l^{\prime}$ subequal to tibial seta $l^{\prime}$. Femur: seta $d$ on femur about 2.5 times as long as seta $v^{\prime \prime}$.

Leg III (Fig. 6). Setal formula: 1-1-4-5. With a pair of claws and large, stalked empodium. Tarsus: seta $p v$ " characteristically modified, lanceolate; setae $p l$ "and $p v^{\prime}$ subequal and shortest on the segment. Tibia: setae $v^{\prime}$ and $v^{\prime \prime}$ subequal; seta $d$ subequal to $l^{\prime}$ and both shorter than $v^{\prime}$ and $v^{\prime \prime}$. Genu: seta $v^{\prime}$ subequal to tibial setae $d$ and $l^{\prime}$. Femur: seta $d$ shorter than seta $v^{\prime}$ on genu.

Leg IV (Fig. 7). Setal formula: 1-1-4-5. With a pair of claws and large, stalked empodium. Tarsus: seta $t c^{\prime}$ longest on the segment; setae $p v^{\prime}$ and $p v^{\prime \prime}$ subequal. Tibia: seta $d$ and $v^{\prime}$ subequal and shorter than other setae on the segment. Genu: seta $v^{\prime}$ subequal to tibial seta $d$ and $v^{\prime}$. Femur: seta $d$ shorter than other leg setae.

Male. Unknown.

Differential diagnosis. The species Pavania lanceolata Bahramian et Hajiqanbar sp. $\mathrm{n}$. is readily distinguished from all other species of the genus by some modified lanceolate setae on tarsus I ( $\left.p v^{\prime}, p v^{\prime \prime}, u^{\prime}, u^{\prime \prime}\right)$, tarsus II $\left(u^{\prime}, t c^{\prime \prime}\right.$, $\left.p v^{\prime}, p v^{\prime \prime}\right)$ and tarsus III ( $\left.p v^{\prime \prime}\right)$. Based on drawings of MaHunKa (1975), at least, tarsus II seta $u^{\prime}$ in Pavania endroedyi Mahunka, 1975 is foliate. Regardless of this trait, the new species is similar to its congeners Pavania fusiformis Lombardini, 1949; P. endroedyi and P. kamalii Hajiqanbar et Khaustov, 2010 in presence of trichobothridia and setae $f$ longer than $e$. The new species differs from Pavania fusiformis by seta $c_{2}$ twice as long as $c_{1}$ (seta $c_{2}$ less than twice as long as $c_{1}$ in $P$. fusiformis), seta $d$ longer than $c_{1}$ (setae $c_{1}$ and $d$ subequal in $P$. fusiformis), seta $s C_{2}$ about 3.5 times longer than $c_{1}$ (seta $s c_{2}$ about 2.5 times longer than $c_{1}$ in $P$. fusiformis). The new species differs from Pavania endroedyi by seta $c_{2}$ two times longer than $c_{1}$ (setae $c_{1}$ and $c_{2}$ subequal in $P$. endroedyi), seta $v_{1}$ longer than $e$ (setae $e$ longer than $v_{1}$ in $P$. endroedyi), distance $d$-d longer than $e-e$ (distance $e$-e longer than $d-d$ in $P$. endroedyi). The new species also differs from Pavania kamalii by seta $c_{2}$ twice as long as $c_{1}$ (seta $c_{1}$ longer than $c_{2}$ in $P$. kamalii), seta $f$ at least three times longer than $e$, (seta $f$ about two times longer than $e$ in $P$. kamalii), seta $d$ longer than $c_{1}$ (seta $c_{1}$ longer than $d$ in $P$. kamalii). 


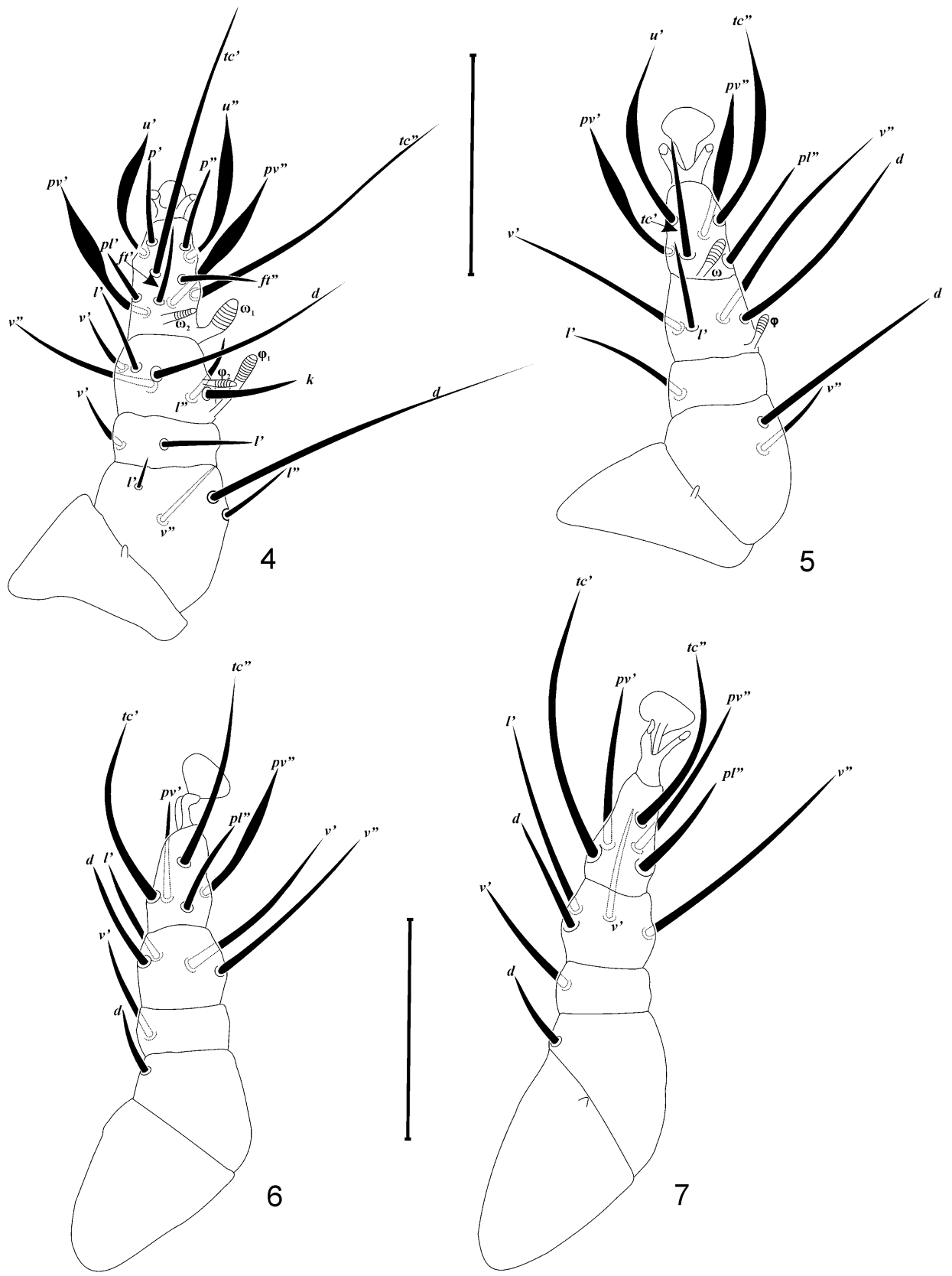

Figs 4-7. Pavania lanceolata sp. n., female, dorsal view of legs: $4=\mathrm{I}, 5=\mathrm{II}, 6=\mathrm{III}, 7=\mathrm{IV}$ (scale bars $20 \mu \mathrm{m})$. 
Type material. Holotype (MB-20130508-1) and four paratypes, recovered from a vial containing ethanol (75\%) and one specimen of Scarabaeus (Scarabaeus) pius (Illiger, 1803) beetle (Coleoptera: Scarabaeidae). The host beetle was collected from its habitat i.e. livestock dung pads, located in Iran, Southern Isfahan Province, near Semirom town, $31.26^{\circ} \mathrm{N}$, $51.29^{\circ} \mathrm{E}, 2,460 \mathrm{~m}, 8$ May 2013, leg. M. Bahramian.

Etymology. The new species is named due to lanceolate shape of some setae on tarsi I-III.

\section{Family Podapolipidae Ewing, 1922 \\ Tarsopolipus massai Husband, 1989}

Material examined. A large colony including all life stages of the mite from under the elytra of Scarabaeus (Scarabaeus) pius (Coleoptera: Scarabaeidae), the same host specimen as for Pavania lanceolata sp. $n$. Host beetle collected from livestock dung pads, Central Iran, Isfahan Province, around Semirom town, $31.26^{\circ} \mathrm{N}, 51.29^{\circ} \mathrm{E}, 2,460 \mathrm{~m}, 8$ May 2013, leg. M. Bahramian.

World distribution. Italy, Iran, France, Spain, East Africa.

Remarks. This is a new association between this parasitic mite and the scarab beetle Scarabaeus pius. All previous host records of this mite are Scarabaeus semipunctatus reported by Husband (1989) in Italy, France, Spain and East Africa; by Hajiqanbar et al. (2007) in the vicinity of Galugah Forest, Mazandaran Province, northern Iran; and by Mortazavi and Hajiqanbar (2012) in Kerman Province, Iran.

\section{DISCUSSION}

The genus Pavania now includes 20 species of which 9 (c. 50\%) are phoretic on 4 genera of Scarabaeidae: Copris, Onthophagus, Gymnopleurous and Scarabaeidae (Cross 1965, Sevastianov 1980, Hajiqanbar \& Khaustov 2010, Rahiminejad et al. 2011, Loghmani et al. 2013, present study). Including Scarabaeus pius as a new host record for mites of the genus Pavania, the number of Scarabaeus species carrying mites of this genus is raised to 8 (see Table 1). All mentioned host beetles are dung dwelling as this habitat provides a rich source of fungi for mite nutrition. Although no life history of the species of Pavania has already been reported, they appear to be fungivorous in this substrate and, perhaps help in spreading fungi spores.

There are five podapolipid genera parasitizing scarab beetles: Dilopolipus Husband, Archipolipus Husband, Stenopolipus Husband, Scarabapolipus Husband et Kurosa, and Tarsopolipus Berlese. Nine species of the genus Tarsopolipus are associated with three scarabaeid genera Drepanopodes, Kheper and Scarabaeus. Including S. pius, six species of Scarabaeus are exploited by mites of the genus Tarsopolipus. Heretofore, Tarsopolipus massai was found only on 
Table 1. Current knowledge on mites of the genus Pavania associated with beetles of the family Scarabaeidae.

\begin{tabular}{|c|c|c|c|}
\hline Mite & Host & Locality & Reference \\
\hline P. riparia & Copris lunaris Linneaus, 1758 & $\begin{array}{l}\text { Ukraine, } \\
\text { Slovakia }\end{array}$ & $\begin{array}{l}\text { SEVAstianov } \\
1980\end{array}$ \\
\hline P. tadjikistanica & Onthophagus sp. & Tajikistan & $\begin{array}{l}\text { Sevastianov } \\
1980\end{array}$ \\
\hline P. fusiformis & Scarabaeus sacer Linneaus, 1758 & Italy & Cross 1965 \\
\hline P. gymnopleuri & $\begin{array}{l}\text { Gymnopleuros mopsus persianus } \\
\text { Reitter, } 1909\end{array}$ & Iran & $\begin{array}{l}\text { HajiQAnbar \& } \\
\text { Khaustov } 2010\end{array}$ \\
\hline P. sabzevarensis & $\begin{array}{l}\text { Gymnopleuros mopsus persianus } \\
\text { Reitter, } 1909\end{array}$ & Iran & $\begin{array}{l}\text { HaJiQAnbar \& } \\
\text { Khaustov } 2010\end{array}$ \\
\hline P. onthophagi & $\begin{array}{l}\text { Onthophagus gibbosus gibbosus } \\
\text { Scriba, } 1790\end{array}$ & Iran & $\begin{array}{l}\text { HajiQAnbar \& } \\
\text { Khaustov } 2010\end{array}$ \\
\hline P. kamalii & Scarabaeus spp. & Iran & $\begin{array}{l}\text { HaJiQAnBar \& } \\
\text { KHAUSTOV } 2010\end{array}$ \\
\hline P. setiformis & $\begin{array}{l}\text { Onthophagus (Palaeonthopha- } \\
\text { gus) vitulus (Fabricius, 1776) }\end{array}$ & Iran & $\begin{array}{l}\text { LOGHMANI et al. } \\
2013\end{array}$ \\
\hline P. lanceolata sp. $\mathrm{n}$. & Scarabaeus pius & Iran & this study \\
\hline
\end{tabular}

Scarabaeus semipunctatus, however, the current study revealed Scarabaeus pius as a new host record for this parasitic mite.

Acknowledgements - We are grateful to Dr. G. V. Nikolaev (Al-Farabi Kazakh National University, Almaty, Kazakhstan), for identifying the scarabaeid beetle host.

\section{REFERENCES}

Bochкov, A. V. \& KLimov, P. B. (2005) Three new species of the predaceous Cheyletidae (Acari: Prostigmata) phoretic on insects. Acarina 13: 15-22.

Costa, M. (1963) The mesostigmatic mites associated with Copris hispanus (L.) (Coleoptera, Scarabaeidae) in Israel. Zoological Journal of the Linnean Society 45: 25-45. doi: 10.1111/j.1096-3642.1963.tb00485.x

Ebermann, E. \& Hall, M. (2003) First record of sporothecae within the mite family Scutacaridae (Acari, Tarsonemina). Zoologischer Anzeiger 242: 367-375. doi: 10.1078/00445231-00110

Hajiqanbar, H. \& Khaustov, A. (2010) A new species group and five new species of the genus Pavania (Acari: Dolichocybidae) associated with insects, with notes on leg chaetotaxy and the distribution of genera. European Journal of Entomology 107: 441-453. doi: 10.14411/eje.2010.051 
Hajiqanbar, H., Husband, R. W., Kamali, K., Saboori, A. \& Kamali, H. (2007) Ovacarus longisetosus n. sp. (Acari: Podapolipidae) from Amara (Paracelia) saxicola Zimm (Coleoptera: Carabidae) and new records of Coccipolipus, Dorsipes, Eutarsopolipus and Tarsopolipus from Iran. International Journal of Acarology 33(3): 241-244. doi: $10.1080 / 01647950708684528$

Hajiqanbar, H., Rahiminejad, V. \& Fathipour, Y. (2012) New insect host records for mites of the family Microdispidae (Acari: Heterostigmatina), with description of a new species of the genus Paramicrodispus. Entomological Science 15: 309-313. doi: 10.1111/j.1479-8298.2012.00515.x

Houck, M. A. \& Oconnor, B. M. (1991) Ecological and evolutionary significance of phoresy in the Astigmata (Acari). Annual Review of Entomology 36: 611-636. doi: 10.1146/annurev.en.36.010191.003143

Husband, R. W. (1989) A revision of the genus Tarsopolipus (Acari: Podapolipidae), parasites of African and European Scarabaeidae, with description of three new species. International Journal of Acarology 15: 163-178. doi: 10.1080/01647958908683842

Kaliszewski, M., Athias-Binche, F. \& Lindquist, E. E. (1995) Parasitism and parasitoidism in Tarsonemina (Acari: Heterostigmata) and evolutionary consideration. Advances in Parasitology 35: 335-367. doi: 10.1016/S0065-308X(08)60074-3

Khaustov, A. \& Trach, V. A. (2012) A new species and new records of mites of the genus Spatulaphorus Rack (Acari: Heterostigmata: Pygmephoridae) from Ukraine. International Journal of Acarology 38: 480-485. doi: 10.1080/01647954.2012.677475

Lindeuist, E. E. (1986) The World genera of Tarsonemidae (Acari: Heterostigmata): a morphological, phylogenetic, and systematic revision, with a reclassification of familygroup taxa in Heterostigmata. Entomological Society of Canada 136: 1-517. doi: 10.4039/ entm118136fv

Loghmani, A. Hajiqanbar, H. \& Talebi, A. A. (2013) A new species group and species of the genus Pavania (Acari: Dolichocybidae), phoretic on Onthophagus vitulus (Coleoptera: Scarabaeidae) from Iran. Zootaxa 3693: 320-328. doi: 10.11646/zootaxa.3693.3.2

Lombardini, G. (1949) Acari nuovi. Redia 34: 67-74.

Mahunka, S. (1975) Auf Insekten lebende Milben (Acari: Acarida and Tarsonemida) aus Afrika. V. Acta Zoologica Academiae Scientiarum Hungaricae 21(1-2): 39-72.

Masan, P. \& Halliday, B. (2009) Mesostigmatid mites associated with the dung beetle Copris lunaris (Coleoptera: Scarabaeidae). European Journal of Entomology 106: 545550. doi: 10.14411/eje.2009.068

Mortazavi, A. \& Hajiqanbar, H. (2012) A new podapolipid species (Acari) on Scarabaeus (Scarabaeus) acuticollis (Insecta: Coleoptera: Scarabaeidae) from Iran. Journal of Parasitology 98: 746-753. doi: 10.1645/GE-3034.1

OconNor, B. M. (1982) Evolutionary ecology of astigmatid mites. Annual Review of Entomology 27: 385-409. doi: 10.1146/annurev.en.27.010182.002125

Rahiminejad, V., Hajiqanbar, H. \& Fathipour, Y. (2011) Redefinition of the genus Dolichocybe (Acari: Dolichocybidae), with description of two new species associated with insects. Annals of the Entomological Society of America 104: 627-635. doi: 10.1603/AN11006

Revised version received February 24, 2014, accepted December 20, 2014, published April 30, 2015 